\title{
MEMÓRIAS E RESISTÊNCIA NA POÉTICA DAS ESCOLAS DE SAMBA
}

\author{
[Memories and Resistance in the Poetics of Samba-Schools]
}

\author{
Jackson Raymundo ${ }^{1}$
}

Resumo: Gênero artístico criado na periferia urbana, o desfile de escolas de samba deu origem a um novo gênero cancional, o samba-enredo, que tem na sua poética a forte presença da História. Reproduzindo as tensões da realidade brasileira, os discursos hegemônicos e contra-hegemônicos, as escolas de samba veem nos períodos de "gritos de contraviolência“" (POLLAK, 1989) extravasar ciclos de crítica política e social na estética de seus desfiles e na poética de sua canção. Neste artigo, após contextualizar a relação entre memória e carnaval, se fará um Estudo de Caso de dois desfiles de 2020, compreendendo-os sob os Estudos Interartes (CLÜVER, 2006): o da Grande Rio, Tata Londirá: o Canto do Caboclo no Quilombo de Caxias, e o da Mangueira, A verdade vos fará livre. Em comum, o fato de evocarem discursos de resistência e fazerem emergir memórias que estavam submersas, silenciadas (POLLAK, 1989), tecendo outras narrativas acerca do imaginário nacional.

Palavras-chave: Samba-Enredo; Carnaval Brasileiro; Escolas De Samba; Canção Popular; Memória.

Abstract: Artistic genre created in the urban periphery, the samba-school parades originated a new song genre, the samba-enredo, which has in its poetics the presence of History. Reproducing the tensions of the Brazilian reality, the hegemonic and counter-hegemonic discourses, the samba-schools see in periods of "screams of contraviolence" (POLLAK, 1989) spill out cycles of political and social criticism in the aesthetics of their parades and in the poetics of their song. In this article, after contextualizing the relationship between memory and carnival, a Case Study of two parades in 2020 will be made, understanding them under Interart Studies (CLÜVER, 2006): that of Grande Rio, Tata Londirá: the Canto do Caboclo in Quilombo de Caxias, and of Mangueira, The truth will set you free. In common, the fact that they evoke speeches of resistance and provoke the emergence of submersed memories, silenced (POLLAK, 1989), building other narratives about the national imaginary.

Keywords: Samba-Enredo; Brazilian Carnival; Samba-Schools; Popular Song; Memory.

1 Doutor em Letras pela Universidade Federal do Rio Grande do Sul, área de concentração Literatura. E-mail: jackson. ufrgs@outlook.com 


\section{INTRODUÇÃO}

O desejo de comunidades periféricas de contar a sua história através de seu próprio olhar e representando-se a si mesmas tem no Brasil uma de suas expressões mais pujantes nos desfiles de escolas de samba.

Muito mais do que um momento de festa e folia, constituiu-se como arte no sentido pleno da palavra. Amalgamando diferentes linguagens artísticas e midiáticas - a música, a dança, a poesia, as artes visuais, o teatro, o circo, a robótica, o cinema, a moda etc. -, as escolas de samba consolidaram um gênero artístico novo, "capaz de rivalizar com as outras grandes manifestações estéticas", como define o intelectual gaúcho Luiz Paulo de Pilla Vares (in: FISCHER \& SEDREZ, 2000, p. 90), que pode ser considerado o "maior complexo de exibições artísticas do mundo moderno" (MUSSA \& SIMAS, 2000, p. 9) Entre as criações advindas dessa nova manifestação cultural tipicamente brasileira, está o samba-enredo, gênero cancional que anualmente se renova e tem o papel de embalar o cortejo de centenas ou milhares de componentes ao longo de um tempo determinado, representando um enredo (texto geralmente em prosa) e reproduzindo aspectos que remontam à tradição e à memória coletiva da agremiação e sua comunidade.

Lugar de escolarização e letramento tardios, e de desigualdades sociais e raciais estruturantes, o Brasil passou diretamente "dos meios orais para o rádio e a televisão (meios de massa), sem passar pelo estágio do letramento sistemático da escola”, afirma José Miguel Wisnik citando uma fala de Antonio Candido (in: OLIVEIRA, 2016), apesar de o país possuir uma "alta literatura". A canção popular, assim, tornou-se um dos principais meios de comunicação de massa, e o espaço encontrado por pessoas oriundas das classes populares para viver de sua arte e narrar o seu cotidiano, seus amores e memórias de si e de seus antepassados.

\section{A CONSTRUÇÃO DE MEMÓRIAS POR MEIO DA CANÇÃO DE CARNAVAL}

Situada entre o campo da cultura oral e da cultura de massa, a canção popular brasileira gradualmente se converteu em um dos principais produtos culturais do país. O samba urbano, gênero fundado por negros da periferia do Rio de Janeiro e impulsionado pelas nascentes indústria fonográfica e a radiofusão, na primeira metade do século XX se firma como o gênero por essência "brasileiro", sendo também o símbolo da "identidade nacional" - tal qual o tango na Argentina e no Uruguai, a cúmbia na Colômbia, o fado em Portugal, entre outros.

Se o samba já se transformava em gênero dominante no rádio e no mercado de discos, o encontro do gênero com o carnaval fez surgir as escolas de samba, no início dos anos 1930, que revolucionariam os eventos momescos. Mais disciplinadas e procurando retratar fatos e personagens da cultura brasileira, em suas primeiras décadas basicamente repetiram as narrativas da historiografia oficial. É a partir dos anos 60 que novas narrativas têm vez, dando visibilidade a heróis e heroínas negros que não estavam nos livros de História, como Zumbi dos Palmares, Chica da Silva, Chico-Rei, entre outros. Manifestação cultural viva, 
abrangente, construída coletivamente, ao longo do tempo as escolas de samba representaram memórias e discursos hegemônicos e contra-hegemônicos, transpondo para o carnaval os variados dissensos que permeiam a complexidade das relações sociais, políticas e econômicas brasileiras.

A memória é vista por Pollak (1989) como o território da disputa. A preferência dada pela história oral à análise dos excluídos pela historiografia hegemônica fez da "empatia com os grupos dominados" uma regra metodológica. A oposição entre "memória oficial" e "memória nacional" é acentuada. Diz o autor:

[a história oral] acentua o caráter destruidor, uniformizador e opressor da memória coletiva nacional. Por outro lado, essas memórias subterrâneas que prosseguem seu trabalho de subversão no silêncio e de maneira quase imperceptível afloram em momentos de crise em sobressaltos bruscos e exacerbados. A memória entra em disputa. Os objetos de pesquisa são escolhidos de preferência onde existe conflito e competição entre memórias concorrentes. (POLLAK, 1989, p. 4)

Com o poder de mobilizar milhares de pessoas e, no caso de cidades como o Rio de Janeiro e São Paulo, serem televisionadas para o Brasil e o mundo, poucas das expressões artísticas de algum modo massivas ecoam tanto para o grande públicas as memórias coletivas das comunidades marginalizadas o quanto os desfiles das escolas de samba. Como diz Pollak, é nos momentos de crise em que as "memórias subterrâneas" afloram e jogam para o centro da arena os conflitos existentes na sociedade.

A questão da memória perpassa terrenos diversos da teoria literária. Está, particularmente, ligada ao épico, gênero sustentado pela tradição oral, pelo discurso coletivo, ou em prol de uma coletividade, e por temáticas que comumente associam-se a disputas entre comunidades, povos, nações. A característica predominantemente oral da épica faz com que não se perca com o tempo; a memória assegura a sua continuidade.

A épica, ainda, está imbricamente ligada à História, diferentemente de outros gêneros literários. Como diz Walter Benjamin (1983, p. 65), "nesse caso, a História se comportaria em relação às formas épicas como a luz branca em relação às cores do espectro". Na tradição grega, Mnemosine é a personificação da memória, que assim sintetiza a simbiose entre épica e memória:

A memória é a capacidade épica por excelência. Só graças a uma memória abrangente pode a épica, por um lado, apropriar-se do curso das coisas e, por outro, fazer as pazes com o desaparecimento delas.

Mnemosina [sic], A que se Recorda, era entre os gregos a musa do gênero épico. [...] A lembrança instituiu a corrente da tradição que transmite o acontecido de geração a geração. Ela é a musa da épica, em sentido lato. Abarca o conjunto das formas singulares do épico, inspiradas por ela. [...] Ela funde a rede que todas as histórias interligadas formam no final. Uma história emenda na outra [...]. Esta memória é épica - o elemento de musa que impele a narrativa. (BENJAMIN, 1983, p. 66-67) 
A historiografia literária, de modo geral, aponta a épica como algo restrito ao passado e de presença escassa no Brasil. Contudo, é no gênero cancional criado por negros da periferia urbana do Rio de Janeiro nas primeiras décadas do século XX, de nenhum ou pouca escolarização, que o gênero renascerá sob nova forma, porém com uma poética que carrega diversas características do tradicional gênero literário. Contrariando a tendência lírica da canção popular contemporânea, o samba-enredo pode ser considerado o "único gênero épico genuinamente brasileiro", definem Mussa \& Simas (2010):

Entre as espécies de samba, o samba de enredo é certamente a mais impressionante. Porque não é lírica - no que contraria uma tendência universal da música popular urbana. $[\ldots]$

Mais do que isso, por que o samba-enredo é um gênero épico. $O$ único gênero genuinamente brasileiro - que nasceu e se desenvolveu espontaneamente, livremente, sem ter sofrido a mínima influência de qualquer outra modalidade épica, literária ou musical, nacional ou estrangeira. (MUSSA \& SIMAS, 2010, p. 9-10)

O gênero samba-enredo surgiu tendo a História como uma de suas marcas principais. Em 1938, a União das Escolas de Samba exige no regulamento dos desfiles a obrigatoriedade de apresentações "de acordo com a música nacional", não permitindo que os enredos trouxessem "histórias internacionais, em sonho ou em figuração" (CABRAL, 2011, p. 128). A regra perdurou até a década de 1990. Essa característica amalgamada à História fez com que os compositores de sambas-enredo criassem "verdadeiros poemas épicos", mesmo "sem qualquer conhecimento didático da estrutura", ressalta Tinhorão (1974, p. 174).

Em tese de doutorado sobre a poética cancional das escolas de samba do Rio de Janeiro - ou seja, sobre o samba-enredo -, Autor (2019), inspirado livremente no modelo historiográfico de Fernand Braudel (1992) adaptado para a teoria literária por Franco Moretti (2008), estrutura a história do gênero em "longuíssimas durações", "longas durações", "ciclos" e "eventos". Entre os "ciclos", que são aqueles em que o amálgama entre história e forma artística se dá de modo mais explícito, estão aqueles de destacada crítica política e/ou social. O pesquisador localizou dois: meados dos anos 1980 até o fim do decênio e os anos finais da década de 2010.

Os dois momentos históricos foram (e são) turbulentos na história do Brasil: o primeiro, marcado pela redemocratização após mais de 20 anos de ditadura militar - e com o fim da censura, a possibilidade de voltar a recorrer a temas e léxicos antes proibidos. No segundo, o país vive uma convulsão após a eleição de 2014, acentuada pela crise econômica, tendo como fatos notórios a operação Lava Jato, o golpe parlamentar de 2016, a retirada de direitos trabalhistas e sociais em 2017, o assassinato de Marielle Franco e a prisão de Lula em 2018, e a ascensão da extrema-direita que culmina na eleição de Jair Bolsonaro.

Se durante os áureos tempos da democracia brasileira os enredos críticos praticamente haviam sumido - assim como ocorrera durante a ditadura, mas por outras razões -, na segunda metade da década de 10 deste século voltam com tudo. A desigualdade social e os ataques contra os direitos dos trabalhadores, a violência policial contra a juventude negra, 
a LGBTfobia, as tragédias ambientais, o preconceito contra os imigrantes, a intolerância religiosa, a perseguição institucional contra o próprio carnaval, praticamente nada escapa.

Para exemplificar, em 2018, a campeã foi a Beija-Flor, com o tema Monstro é aquele que não sabe amar. Os filhos abandonados da pátria que os pariü; a agremiação cantou versos como "Oh, pátria amada, por onde andarás? / Seus filhos já não aguentam mais”. Surpreendendo, a vice-campeã Paraíso do Tuiuti, no melhor resultado de sua história, abordou os 130 da abolição, questionando: Meu Deus, meu Deus, está extinta a escravidão?33 em seu desfile, patos batendo panelas manipulados como marionetes, uma carteira de trabalho rasgada, entre outros elementos cênicas, representavam um posicionamento perante aquele contexto histórico.

Em 2019, a campeã foi a Mangueira, com o enredo História pra ninar grande 4 , que buscou desconstruir a narrativa hegemônica ao contar a "história que a história que não conta", como fala um de seus versos. Já na comissão de frente, uma galeria de heróis emoldurados é desfeita e eles, fora do quadro, são minúsculos: seus lugares são tomados por índios, negros e pobres e uma menina negra, segurando uma faixa com a inscrição "Presente", remete a Marielle e à maioria do povo que não se viu representada nos livros de História até agora. Diversos de seus versos se tornaram antológicos no refazimento do que seria a memória nacional: "Desde 1500 tem mais invasão do que descobrimento"; "Eu quero um país que não está no retrato"; "Não veio do céu / Nem das mãos de Isabel / A liberdade é um dragão no mar de Aracati"; "Brasil, chegou a vez / De ouvir as Marias, Mahins, Marielles, malês".

O número de enredos críticos foi crescendo ano a ano, até se tornar praticamente uma regra implícita no carnaval de 2020. Sob enfoques bastante distintos, todas as escolas de samba fizeram alguma manifestação crítica - seja no samba ou no desfile, ou em ambos. Para o corpus deste trabalho, foram selecionados dois desfiles que tiveram em comum a temática religiosa: o da Grande Rio, escola que ficou com o vice-campeonato, cujo título foi Tata Londirá: o Canto do Caboclo no Quilombo de Caxias; e o da Mangueira, que buscou apresentar uma narrativa contra-hegemônica sobre Jesus Cristo através do enredo A verdade vos fará livre.

Antes de seguir, alguns pressupostos. Primeiro, como referido inicialmente, entende-se aqui o desfile de escolas de samba não como mera "folia" carnavalesca, e sim como gênero artístico, com uma profusão de linguagens concomitantes. Nisso, são de bastante valia como referências teóricas os Estudos Interartes e os Estudos de Intermidialidade (CLÜVER, 2006). Ao analisar o objeto simbólico na centrifugação de diferentes linguagens artísticas ou midiáticas, essa perspectiva auxilia na análise de uma forma que é por essência mista, incapaz de ser devidamente estudada em sua complexidade sob apenas um ângulo.

[...] elementos verbais, visuais, auditivos, cinéticos e performativos agem conjuntamente, as disciplinas dedicadas às artes tradicionais, frequentemente, têm

\footnotetext{
2 BEIJA-FLOR, 2018: "Monstro é aquele que não sabe amar. Os filhos abandonados da pátria que os pariu". Autoria do samba-enredo: Di Menor BF, Kiraizinho, Diego Oliveira, Bakaninha Beija Flor, JJ Santos, Julio Assis e Diogo Rosa.

3 PARAÍSO DO TUIUTI, 2018: “Meu Deus, meu Deus, está extinta a escravidão?”. Autoria do samba-enredo: Cláudio Russo, Moacyr Luz, Jurandir, Zezé e Aníbal.
}

4 MANGUEIRA, 2019: "História pra ninar gente grande”. Autoria do samba-enredo: Deivid Domênico, Tomaz Miranda, Mama, Marcio Bola, Ronie Oliveira, Danilo Firmino e Manu da Cuíca. 
dado pouca atenção a essas formas mistas que surgem em seu âmbito e não desenvolveram quaisquer métodos adequados que lhes fizessem justiça - até que elas se tornaram um objeto de estudo importante para os Estudos Interartes. $\mathrm{O}$ fenômeno dessas formas mistas também é denominado, no uso corrente alemão, “intermidialidade". (CLÜVER, 2006, p. 19)

Além desse encontro de linguagens que funda uma manifestação artística nova, exigindo também novos parâmetros de análise, o desfile de escolas de samba possui como algumas de suas características a competitividade, já que as entidades disputam um certame anual subordinado a regras, carregam a representação de uma bandeira e sua comunidade, o que acentua o tom coletivo da exibição e a ideia de continuidade de uma tradição. Por fim, sublinha-se que é no que pese as escolas de samba terem vida ao longo do ano e ser o desfile precedido de muitos ensaios e do trabalho de diversos setores, é na avenida que ele se concretiza. Não há alegoria, samba-enredo, encenação de comissão de frente ou bateria que se realize fora da passarela, no tempo estipulado.

Assinalando o que é próprio dos estudos de canção, ressalta-se que não basta se limitar à letra da canção. Gênero também híbrido, a canção é feita de letra e melodia. No caso do samba-enredo, a sua análise deve se consolidar é na performance no decorrer do desfile, ainda que a canção seja conhecida antes de sua entrada na "avenida".

Do mesmo modo, tem-se como pressuposto que a análise do samba-enredo não pode estar dissociada de sua performance e sua representação no desfile, ainda que tecnicamente seja impossível um olhar global do mesmo - na literatura escrita, todo o conteúdo está na palavra publicada; no cinema, tudo se passa nos limites da tela; na música, o contato se faz na audição da gravação; enquanto isso, no desfile de escolas de samba cada espectador assiste um fragmento de uma apresentação que reúne milhares de integrantes e que não é a mesma ao longo do percurso.

Diante desses pressupostos, o estudo de caso analisará não apenas os sambas-enredo de 2020 das escolas escolhidas, Grande Rio e Mangueira, mas também a sua performance no desfile, além do próprio desfile.

\section{ESTUDO DE CASO: OS DESFILES E OS SAMBAS-ENREDO DE GRANDE RIO E MANGUEIRA EM 2020}

O carnaval de 2020 no Rio de Janeiro, mantendo a tendência da segunda metade da década de 2010, foi repleto de temas e versos de crítica política e/ou social. Algumas foram mais diretas, como a Portela, que, ao falar dos indígenas que formaram o Rio de Janeiro, exclama, numa menção implícita ao "capitão" presidente da República e ao "bispo" prefeito: "Índio pede paz, mas é de guerra / Nossa aldeia é sem partido ou facção / Não tem bispo, nem se curva a capitão". Outras agremiações desenvolveram enredos e letras mais sutis na sua crítica, como o Salgueiro, que homenageou Benjamin de Oliveira, o primeiro palhaço negro do Brasil: "A luta me fez majestade / Na pele, o tom da coragem / Pro que está por 
vir... / Sorrir é resistir!", diz a letra, simbolizando na pele negra a coragem e invocando a resistência por meio do humor - e, de modo extensivo, pela arte.

A transformação do carnaval carioca em fins da década de 10 é concomitante à ascensão de uma nova geração de carnavalescos ${ }^{5}$. Em um contexto de escassez econômica e de mudanças políticas que atingiram fortemente o carnaval, o padrão financeiro do evento mudou bastante, fazendo com que os dirigentes procurassem nomes menos conhecidos, e mais adequados à nova realidade, para dirigir a parte artística de suas escolas. Isso propiciou uma significativa revitalização retórica e estética, em que ganha destaque o enredo mais "conceitual" em detrimento dos enredos patrocinados ou de celebração a pessoas famosas. Daniela Name (2020) compara esses novos carnavalescos, a quem chama de "geração de narradores", aos mestres populares da tradição oral, os griôs.

Esta geração de narradores age como os mestres da tradição oral com origem nas muitas nações indígenas e identidades africanas que irrigam nossa cultura popular. Griôs. Primos-irmãos, em nosso território, da personagem Sherazade, de As mil e uma noites, eles apostam na narrativa bem construída como uma forma de sobrevivência e conquista de mais uma aurora, mais uma passagem da escola da qual assinam a direção artística.

Todos os carnavalescos citados por Name são referenciais quando se fala desse ciclo do carnaval de fins dos anos 2010: Leandro Vieira, a dupla Leonardo Bora e Gabriel Haddad, Jack Vasconcelos e Jorge Silveira. A autora não aprofunda em seu texto, mas pode-se incluir aí nomes como Marcus Ferreira e Tarcísio Zanon, carnavalescos da Viradouro, campeã do carnaval 2020, também com enredo “conceitual”. Para esta análise, serão aprofundados os desfiles assinados por Leonardo Bora e Gabriel Haddad na Grande Rio e por Leandro Vieira na Mangueira.

\subsection{GRANDE RIO: TATA LONDIRÁ: O CANTO DO CABOCLO NO QUILOMBO DE CAXIAS}

Após tropeços nos anos anteriores - a penúltima colocação em 2018 e, na sequência, uma "virada de mesa" para reverter o rebaixamento, e um modesto $9^{\circ}$ lugar em 2019 -, a Grande Rio decidiu olhar para dentro de sua própria comunidade e fazer o seu primeiro enredo de temática negro-brasileira desde 1994 homenageando uma personalidade da cidade de Duque de Caxias, sede da escola: o babalorixá e bailarino Joãozinho da Goméia. Através desse reconhecimento, o enredo tematizou também a intolerância religiosa contra a religiosidade de matriz africana, apresentando o samba-enredo mais comemorado do ano de 2020.

O propósito de evocar uma personalidade que mexesse com a memória coletiva da comunidade de Duque de Caxias estava claro para os carnavalescos, bem como a intenção de visibilizar uma figura esquecida pela historiografia oficial. Disse Leonardo Bora em entrevista (SOUZA, 2020):

5 Para quem não é familiarizado com o universo das escolas de samba, explica-se que "carnavalesco" é o nome dado ao responsável pela direção artística do desfile. Portanto, uma figura central para o bom desempenho da agremiação. 
"Determinados veículos da imprensa acompanhavam cada passo dele, o enterro foi um mega acontecimento e que está fixado na memória coletiva da cidade de Caxias, sendo amplamente noticiado por toda a imprensa televisiva, radiofônica e escrita no Brasil. É mesmo uma grande celebridade, mediador cultural e artista que não está no panteão da glória perante muitas pessoas, que ainda perguntam 'quem foi Joãozinho?' então o carnaval tem esse papel social, de olhar para figuras apagadas, que passaram por uma espécie de apagamento histórico que está diretamente relacionado ao racismo, a homofobia, ao preconceito que permanece infelizmente agindo contra as religiões de matriz africana."

A seguir, descreve-se e comenta-se fragmentos do desfile da Grande do Rio a partir do acompanhamento da cobertura televisiva (TV Globo) e de observações próprias do autor ao assistir a apresentação no sambódromo.

A Comissão de Frente, intitulada "Ponto riscado", exibe as saias das iaôs se transformando em roncó, que é a casa do caboclo. Após um momento em que o guia espiritual de Joãozinho da Goméia, o Pedra Preta, dança sozinho, as baianas viram caboclos, saem do roncó e sobem em um elemento cenográfico retratando um lago, onde, nas águas, a performance expressa a passagem de Joãozinho da infância à juventude e à vida adulta. Um enorme leque se abre na parte traseira da performance salta a frase "Respeita o meu axé", junto do símbolo da escola.

O mestre-sala e a porta-bandeira, representando "Exu e pomba-gira", são os responsáveis por "pedir licença". Cercados por guardiões, encenam movimentos dos orixás e são seguidos da ala "Noites de Ihambupe", que retrata os sonhos e pesadelos de Joãozinho na infância.

O carro abre-alas, ponto alto de toda escola de samba, teve como motivo "Raízes ancestrais". Com uma estética bastante africana, com máscaras geledés, esculturas em palhas, animais típicos etc., teve também a inspiração icônica nas pinturas de Caribé. A tradicional ala das baianas desfilou fantasiada de "Festa na Goméia". O segundo carro alegórico teve como título "Xirê: Foi na roça da Goméia, aos pés de uma gameleira", exibindo esculturas, algumas móveis, de diversos orixás. Foi procedido por alas como "Caboclo jaguará - Terra”; "Caboclo taperoá - Fogo"; "Caboclo ventania - Ar"; "Cabocla jurema - Água”, até chegar ao terceiro carro. Em "Quando baixam os caboclos na Baixada", a Goméia é transformada em festa dos caboclos; a estética é indígena, com grafismo de diferentes povos nativos.

A homossexualidade e o lado carnavalesco do protagonista são representados no quarto setor, que traz alas simbolizando as vedetes, o segundo casal de mestre-sala e porta-bandeira, com o tema "Cores do arco-íris", cercado por guardiões com um arco-íris na cabeça, referenciando-se tanto a Oxumaré quanto à comunidade LGBT. O tripé "Pavão Dourado" carrega a lembrança de quando Joãozinho se vestia inspirado na vedete Virgínia Lane. A alegoria "Um saravá pra folia" sintetiza as facetas carnavalesca e queer de Joãozinho da Goméia, com mais de 30 drag queens, serpentinas e outros elemento da cultura momesca.

O último setor apresenta o lado "influente" do homenageado e fecha com uma invocação da tolerância religiosa. Alas exibem estandartes estampando o rosto de personalidades que visitaram o terreiro de Goméia, como Getúlio Vargas; o grupo performático encena 
"Balé afro", remetendo à experiência do protagonista como bailarino e professor de dança e ao seu papel relevante para a popularização das danças dos orixás; uma ala tematiza Copacabana Mon Amour, filme de 1970 dirigido por Rogério Sganzerla, que teve a participação de Joãozinho. Um tripé intitulado "Quem faz a sua gira com fé” mistura o ambiente do cassino da Urca à estética africana. Alas referem-se à militância negra (a ala mirim "Sementes do quilombismo") e ao candomblé ("Raio de Iansã, vento de matamba"; "Herdeiros da Goméia - povo de axé" e, para encerrar, o carro alegórico final, "O revoar da liberdade", traz como destaques Mãe Sandra da Goméia, a herdeira espiritual de Joãozinho, lideranças religiosas de diferentes credos e personalidades negras, como a escritora Conceição Evaristo.

O samba-enredo ${ }^{6}$ da Grande Rio, tal qual no desfile, inicia com uma invocação ao caboclo de Joãozinho da Goméia, o Pedra Preta. Outros caboclos e orixás que remetem à trajetória de Goméia são chamados, reforçando a proteção espiritual para o desfile.

É pedra preta!

Quem risca ponto nesta casa de caboclo

Chama flecheiro, lírio e arranca toco

Seu "serra negra" na jurema, juremá

Pedra preta!

O assentamento fica ao pé do dendezeiro

$\mathrm{Na}$ capa de Exu, caminho inteiro

Em cada encruzilhada um alguidar

As diferentes faces de Joãozinho são narradas na segunda estrofe. No trecho, bem como no conjunto da letra, por vezes é permitida mais de uma leitura semiótica. Os versos são mais simbólicos do que descritivos. A versificação melódica garante uma sonoridade que se aproxima de danças rituais do candomblé.

Era homem, era bicho flor

Bicho homem, pena de pavão

A visão que parecia dor

6 ACADÊMICOS DO GRANDE RIO, 2020: “Tata Londirá: o Canto do Caboclo no Quilombo de Caxias”. Autoria do samba-enredo: Dere, Robson Moratelli, Rafael Ribeiro e Toni Vietnã. 
Avisando Salvador, João!

No camutuê Jubiabá

Lá na roça a gameleira

"Da Goméia" dava o que falar

Na curimba feiticeira

Após o refrão intermediário invocar o orixá Oxóssi, a estrofe seguinte prossegue na narração de aspectos da vida de Joãozinho da Goméia. A sua saga da Bahia até Duque de Caxias, onde forma o terreiro que seria nacionalmente conhecido, é destacada. O verso "malandro, vedete, herói, faraó" busca sintetizar a multiplicidade de personalidades que envolvem o personagem.

\author{
É isso, dendê e catiço \\ O rito mestiço que sai da Bahia \\ E leva meu pai mandingueiro \\ Baixar no terreiro, Quilombo Caxias
}

Malandro, vedete, herói, faraó

Um saravá pra folia

Bailam os seus pés

E pelo ar o bejoim

Giram presidentes, penitentes, yabás

Curva-se a rainha

E os ogans batuqueiros pedem paz

O refrão derradeiro é uma explosão. Após uma saudação vibrante ao candomblé, a afirmação do nome religioso de Joãozinho - Tata Londirá -, a letra finaliza com um apelo à tolerância religiosa.

Salve o candomblé, eparrei Oyá 
Grande Rio é Tata Londirá

Pelo amor de Deus, pelo amor que há na fé

Eu respeito seu amém

Você respeita meu axé

\subsection{MANGUEIRA: A VERDADE VOS FARÁ LIVRE}

A proposta do carnavalesco Leandro Vieira para o desfile da Estação Primeira de Mangueira foi ousada: contar a biografia de Jesus Cristo, a figura mais central da civilização ocidental. Porém, em uma perspectiva alternativa, contra-hegemônica. Em tempos de polarização política em boa medida permeada pelo fundamentalismo e por pós-verdades, foi o desfile bastante atacado antes e depois pelas redes e por líderes da extrema-direita.

Já na comissão de frente a perspectiva ficava bastante explícita. Intitulada "Seu nome é Jesus da gente", tem como primeiro cenário cubos coloridos que formam, simultaneamente, um palco e uma cruz. Buscando refletir sobre quem seriam os amigos de Cristo hoje, surge a "galera do rolé"; o figurino é de jovens da periferia (jeans rasgados, bonés, muito colorido). Na performance, os quadrados se levantam, dando origem à palavra "Jesus". Enquanto os jovens dançam, a polícia surge para "dar uma dura" neles, colocando todos contra a parede e dando-lhes cacetadas, encobrindo o nome "Jesus". O próprio Jesus Cristo é agredido pela polícia. Os cubos se transformam em baile funk na favela da Mangueira e na quadra da escola. É lá que Jesus ressuscita.

$\mathrm{Na}$ sequência, o casal de mestre-sala e porta-bandeira: ele de Jesus, com uma coroa de espinhos; ela de Mangueira. Na representação, Jesus corteja a escola. Em certo momento da performance, na estrofe iniciada com "Favela, pega a visão...", os passos de samba se convertem em funk, no compasso dado pela bateria no trecho.

O primeiro tripé mostra a chegada dos três reis magos. O carro abre-alas, "O Menino Jesus", mostra um Jesus negro na manjedoura. Ao lado dele, o cantor e compositor Nelson Sargento, presidente de honra da Mangueira, representa José, e a cantora Alcione é Maria. Atrás e bem grande, um Menino Jesus rei e negro, em estilo barroco, cercado por anjos tocando instrumentos musicais.

Um setor representando as passagens bíblicas e as parábolas traz é seguido por um Cristo, maltrapilho, chegando a Jerusalém sobre um burro. O nome do elemento cenográfico é "Cristo em situação de rua". O segundo carro, chamado de "O templo transformado em mercado", traz o ator Humberto Carrão interpretando "Jesus combativo", remetendo à passagem em que expulsa os mercenários da fé. Em tons mais escuros, alas simbolizam os personagens malquistos: fariseus, Herodes, Pôncio Pilatos... A bateria desfila de caveira e, de modo inédito, a rainha da bateria, fantasiada de "Jesus mulher", não samba. 
O terceiro setor exibe as dores e o martírio de Cristo. O carro alegórico "As faces dolorosas da paixão" destaca um coração esfaqueado; nas laterais, pinturas e esculturas que remetem à Via Sacra; nas faces do Jesus carregando a cruz, ele é negro, índio, mulher.

Para não deixar dúvidas da faceta humanista escolhida para o enredo, a ala das baianas tem como tema "A intolerância é uma cruz": as anciãs representam as ialorixás que têm seus templos vilipendiados pelo fundamentalismo. Uma ala traz a frase "Bandido bom é bandido morto" inscrita numa cruz; o rosto aparece semi-coberto e, na frente da fantasia, "Fé no pai".

O quarto carro, chamado "O calvário", apresenta aquela que foi possivelmente a imagem do carnaval 2020. Uma grande cruz traz uma escultura de Jesus como um jovem mestiço e de cabelo descolorido, com o corpo crivado de balas; acima da cruz, a inscrição "Negro". A veste é apenas um pano em verde e rosa. Em volta, diversos outros crucificados: os/as LGBT, as mulheres, os negros etc.; sua cruz carrega a inscrição "Só ame".

A parte final do desfile representa a ressurreição de Jesus Cristo. A ala "Maria Madalena ano 2000" tem como fantasia um véu e um esplendor nas cores do arco-íris, símbolo do movimento LGBT, com cruz de espinho na cabeça e a frase "Vai tacar pedra?" no estandarte. No setor ainda desfilam grupos tradicionais da escola, como a Velha Guarda e as musas. Fechando, o último carro alegórico, "Jesus ascende ao céu", carnavaliza a narrativa. Numa reprodução do morro de Mangueira, ao centro uma escultura de Jesus (negro) segura balões em forma de coração no verde-rosa da escola, num clima de festa e alegria.

O amálgama entre o desfile e o samba-enredo ${ }^{7}$ é total. A primeira estrofe apresenta quem é o "Jesus da gente". Não é aquele homem branco de olhos claros da iconografia cristã eurocêntrica. É negro, índio, mulher, um moleque do Buraco Quente - uma das comunidades do morro de Mangueira.

Eu sou da Estação Primeira de Nazaré

Rosto negro, sangue índio, corpo de mulher

Moleque pelintra do Buraco Quente

Meu nome é Jesus da gente

Longe de ser um filho das elites, tampouco um acomodado, esse Jesus é de família pobre e disposto a lutar. O verso final da estrofe, bisado, conecta a narrativa do enredo ao universo das escolas de samba.

Nasci de peito aberto, de punho cerrado

Meu pai carpinteiro desempregado

7 ESTAÇÃO PRIMEIRA DE MANGUEIRA, 2020. “A verdade vos fará livre”. Autoria do samba-enredo: Manu da Cuíca e Luiz Carlos Máximo. 
Minha mãe é Maria das Dores Brasil

Enxugo o suor de quem desce e sobe ladeira

Me encontro no amor que não encontra fronteira

Procura por mim nas fileiras contra a opressão

(BIS) E no olhar da porta-bandeira pro seu pavilhão

A crítica começa a se acentuar a partir da terceira estrofe. Em tom de questionamento, o eu-cancional se revolta contra a indiferença e à falta de compreensão daquilo que seria a sua verdadeira mensagem. O verso "Porque de novo cravejaram o meu corpo" remete ao extermínio da juventude negra, um problema onipresente na realidade brasileira.

Eu tô que tô dependurado

Em cordéis e corcovados

Mas será que todo povo entendeu o meu recado?

Porque de novo cravejaram o meu corpo

Os profetas da intolerância [...]

Invocando a necessária solidariedade para que haja um futuro decente, o trecho seguinte também faz uma das mais contundentes críticas ao presidente Jair Messias Bolsonaro, entusiasta da indústria armamentista:

Favela, pega a visão

Não tem futuro sem partilha

Nem messias de arma na mão

Favela, pega a visão

Eu faço fé na minha gente

Que é semente do seu chão

Versos posteriores trazem referências às raízes da comunidade mangueirense e ao seu desejo de dias melhores. O refrão final celebra outro tipo de fé, a fé no samba, e, indiferente 
às acusações de pecado, reforça o compromisso com a continuidade dessa tradição.

\author{
Mangueira \\ Samba, teu samba é uma reza \\ Pela força que ele tem \\ Mangueira \\ Vão te inventar mil pecados \\ Mas eu estou do seu lado \\ E do lado do samba também
}

\title{
4 CONSIDERAÇÕES FINAIS
}

Em quase um século de existência, as escolas de samba constituíram-se como gênero artístico, além de fundarem gêneros nas diferentes linguagens artísticas. Revolucionaram o carnaval e ajudaram a formar um símbolo de "brasilidade" para dentro do país e o exterior. Na canção popular, o seu gênero samba-enredo construiu uma verdadeira "poética da brasilidade", assentada simultaneamente nas memórias comunitárias e na representação de memórias nacionais, na reprodução de discursos hegemônicos e na afirmação de discursos contra-hegemônicos, na manutenção do status quo e na resistência ao poder dominante. Uma poética radicada na diversidade como elemento distintivo do povo brasileiro.

A noção de pertencimento está interligada à formação de coletividades, entre elas a nação, e levando-se para o plano estudado neste texto, para uma escola de samba e a sua performance no transcurso de um desfile. Diz Pollak:

A memória, essa operação coletiva dos acontecimentos e das interpretações do passado que se quer salvaguardar, se integra. como vimos, em tentativas mais ou menos conscientes de definir e de reforçar sentimentos de pertencimento e fronteiras sociais entre coletividades de tamanhos diferentes: partidos, sindicatos, igrejas. aldeias. regiões, clãs, famílias, nações etc. (POLLAK, 1989, p. 9)

Esse pertencimento é marcado por tensões entre forças dominantes e dominadas e, ainda que a vitória das primeiras tenha como consequência o trauma e a imposição de um esquecimento, há um intervalo, que "pode contribuir para reforçar a amargura, o ressentimento e o ódio dos dominados, que se exprimem então com os gritos da contraviolência" (POLAK, id., p. 9). 
São esses "gritos de contraviolência" das memórias oprimidas ou esquecidas ao longo de um período histórico que geram momentos na cultura, e aqui destacadamente na narratividade das escolas de samba, em que a estética e o discurso se transformam em arma para aqueles que estavam silenciados. Nesses ciclos imbricados com a História, a potência simbólica e política das escolas adquire outro patamar.

Os desfiles e canções mencionados no Estudo de Caso são bons exemplos da potência que as escolas de samba se convertem nesses "ciclos críticos" do carnaval.

A Mangueira, após o desfile apoteótico de 2019, quando a imagem de Marielle Franco e de outros heróis e heroínas "que a história não conta" carregou a escola para um desfile emocionado e tecnicamente perfeito (não perdeu um décimo sequer na apuração), em 2020 manteve a relevância e seus questionamentos ecoaram fortemente no debate público. A tentativa de demonstrar um Jesus Cristo bem diverso daquele berrado por certas lideranças religiosas não só provocou memórias individuais que cotidianamente se incomodam com o fundamentalismo, como tentou construir outra memória acerca da personagem basilar da civilização ocidental. A Grande Rio, por sua vez, evocou uma figura querida por sua comunidade, reanimando uma memória que estava adormecida na própria agremiação, e fez um brado em defesa da tolerância religiosa e contra as discriminações.

Em sua trajetória de nove décadas, as escolas de samba foram uma das manifestações que, sob qualquer perspectiva, mais conseguiram retratar o Brasil e seus contrastes. Na sua sazonalidade, mostram que, talvez, é no carnaval que o povo brasileiro pode ser quem realmente - e é quando as memórias que estavam submersas, esquecidas, silenciadas, encontram as melhores condições para emergirem. 


\section{REFERÊNCIAS}

AUTOR. Tese (Doutorado em Letras) - xxxxxxxxxx

BENJAMIN, W. et. al. Textos escolhidos. São Paulo: Abril Cultural, 1983.

BRAUDEL, F. Escritos sobre a História. 2a Ed. São Paulo: Perspectiva, 1992.

CABRAL, S. As escolas de samba do Rio de Janeiro. São Paulo: Lazuli Editora: Companhia Editora Nacional, 2011.

CLÜVER, C. Da transposição intersemiótica. In: ARBEX, Márcia (org.). Poéticas do visível: Ensaios sobre a escrita e a imagem. Belo Horizonte: Programa de Pós-Graduação em Estudos Literários. FALE/ UFMG, 2006, p. 107-166.

MORETTI, F. A literatura vista de longe. Tradução de Anselmo Pessoa Neto. Porto Alegre: Arquipélago Editorial, 2008.

MUSSA, A.; SIMAS, L. A. Samba de enredo: história e arte. Rio de Janeiro: Civilização Brasileira, 2010. 238p.

NAME, D. Uma geração de narradores. Disponível em: http://revistacaju.com.br/2020/03/07/umageracao-de-narradores/. Acesso em: maio de 2020.

OLIVEIRA, D. "A ligação entre música e literatura é forte”, diz Wisnik. A Tarde, 2016. Disponível em: http://atarde.uol.com.br/cultura/noticias/1754461-a-ligacao-entre-musica-e-literatura-eforte-diz-wisnik-premium. Acesso em: maio de 2020.

PILLA VARES, L. Samba: a arte total. In: FISCHER, Luís Augusto; SEDREZ, Mariângela (org.). Conversas entre confetes. Porto Alegre: Secretaria Municipal da Cultura, 2000. P. 87-97.

POLLAK, M. Memória, esquecimento, silêncio. Estudos Históricos. Rio de Janeiro, v. 2. n. 3, 1989, p. 3-15.

SOUZA, G. Gabriel Haddad e Leonardo Bora, carnavalescos da Grande Rio: 'Não existe o 'correto' em arte'. Carnavalesco, 2020. Disponível em: https://www.carnavalesco.com.br/gabriel-haddad-eleonardo-bora-carnavalescos-da-grande-rio-nao-existe-o-correto-em-artel. Acesso em: maio de 2020.

TINHORÃO, José R. Pequena história da música popular brasileira: da modinha à canção de protesto. Petrópolis: Vozes, 1974. 